\title{
Physiological Changes After Spa Treatment - a Focus on Endocrinology
}

\author{
M. BICIKOVA ${ }^{1}$, L. MACOVA ${ }^{1}$, L. KOLATOROVA ${ }^{1}$, M. HILL ${ }^{1}$, J. NOVOTNY $^{2}$, \\ D. JANDOVA ${ }^{3}$, L. STARKA ${ }^{1}$
}

${ }^{1}$ Institute of Endocrinology, Prague, Czech Republic, ${ }^{2}$ Priessnitz Spa, Jeseník, Czech Republic,

${ }^{3}$ Medical Faculty of Charles University, Prague, Czech Republic

Received June 21, 2018

Accepted August 31, 2018

\section{Summary}

The paper presents the results of our effort to reveal objective parameters for evaluation of the spa treatment for patients with anxiety-depressive disorders. The study was based on our previous experience with neuroactive steroids and neurosteroids, which play a crucial role in the psychological well-being of patients by maintaining balance of the organism. A total number of 94 steroids were determinated in a group of 70 female patients diagnosed with anxiety-depressive disorders. Patients underwent a month spa treatment while maintaining unchanged medication dosing with SSRI (selective serotonin reuptake inhibitors). The other investigated factors contributing to improving the health of treated subjects were amino-acid homocysteine and serotonin. The blood samples were collected at the beginning and the end of the spa treatment. Serotonin in all patients increased by a relative $23 \%$ (results given as relative differences in percent), while homocysteine decreased by $17.1 \%$. Statistically significant increases were found in 21 steroids, which indicate activation of the adrenal cortex. It can be assumed, that the overall improvement in the mental condition of patients, which was proved by questionnaire from Knobloch and Hausner, the increase in immune suppressive substances and anti-autoimmune responses, will maintain for a longer time after the spa treatment.

\section{Key words}

Neuroactive steroids • Serotonin • Anxiety-depressive disorder • Homocysteine

\section{Corresponding author}

M. Bičíková, Institute of Endocrinology, Národní 8, 11694

Prague 1, Czech Republic. E-mail: mbicikova@endo.cz

\section{Introduction}

Several weeks stays at spas are a commonly prescribed treatment option in many Central European countries, and many such stays are at least partially reimbursed by health insurances. Patients who follow the spa's regime and the advice of doctors, and have completed a spa treatment, report feeling great afterwards. This is a subjective feeling, though, and opponents of spa treatments, which are unarguably costly, claim that this is merely the result of the patient being relieved of their daily stresses from work and family. However, for many the positive effects of spa treatments continue long after returning to regular daily life. Unfortunately, evidence-based objective evaluations of patient status are as yet lacking.

Here we attempted to identify objective parameters for evaluating the results of spa treatments for patients suffering from psychiatric disorders. We focused on neuroactive steroids and neurosteroids, which play a critical role in the psychic health of patients, as shown in our studies as well as those from around the world (Bicikova et al. 2015, Bicikova et al. 2011, Bicikova et al. 2013, Duskova et al. 2015, Reddy 2003, Romer et al. 2009).

Beside de novo production of neurosteroids in brain the precursors may come from the circulation after crossing the hematoencephalic barrier, including steroid hormones produced in the peripheral endocrine system glands such as the adrenal glands (Compagnone and Mellon 2000). In the central nervous system (CNS), they mainly act on two basic types of receptors: $\gamma$-aminobutyric acid receptors $\left(\mathrm{GABA}_{\mathrm{A}}\right.$, permeable to $\mathrm{Cl}^{-}$ions), and N-methyl-D-aspartic receptors (NMDA, 
permeable to $\mathrm{Ca}^{2+}$ ions). The effects of the positive modulation of both types of receptors work against each other, and ensure organismal balance. The most well known steroid acting as a positive modulator of $\mathrm{GABA}_{\mathrm{A}}$ receptors is allopregnanolone, with affects similar to benzodiazepine, and lower levels of this steroid (due to reduced $5 \alpha$-reductase activity) leads to neurotic disorders such as premenstrual syndrome (Guennoun et al. 2015).

The second type of receptor in the CNS is positively modulated primarily by pregnenolone sulfate or dehydroepiandrosterone sulfate. Positive modulation of NMDA receptors leads to excitation and improved memory (Hampl and Bicikova 2010, Schumacher et al. 2008, Vallee et al. 2001).

Other factors of endocrine character that most clearly are influenced are serotonin and homocysteine.

Much has been written about the amino acid homocysteine, which is a non-specific parameter. This amino acid is produced from the metabolism of the essential amino acid methionine as a by-product, where it is either recycled again to methionine or to the non-essential amino acid cysteine, an important component of proteins. The metabolism of homocysteine is influenced by folic acid, and vitamins B6 and B12. If these are not present in sufficient quantities, there is a metabolic dysfunction and homocysteine accumulates in the blood, leading to so-called hyperhomocysteinemia (Bhatia and Singh 2015, Moretti et al. 2017, Sosvorova et al. 2014). Until recently, high levels of homocysteine were mainly seen accompanying cardiovascular diseases, but now they are found in a wide range of so-called "diseases of civilization" such as depression, Alzheimer's disease, Parkinson's disease, multiple sclerosis, migraines, chronic fatigue syndrome, allergies, lowered immunity, and hydrocephalus (Sosvorova et al. 2015a).

The positive effects of serotonin need no introduction (Joling et al. 2018). The precursor of this "happiness hormone" (L-tryptophan) can be purchased as a dietary supplement and is often discussed in literature as inducer of serotonin production (Gibson 2018). The balanced diet and healthy movement obtained in spas along with relaxation lead to normalized levels of homocysteine and serotonin, and thus play a role in the increased health of patients.

\section{Methods}

\section{Patients}

All patients suffered some form of anxietydepressive disorders (International classification of mental disorders; ICD 10 or MKN-10 F4.). During patient selection, care was taken to ensure that they were in a stabilized state. Patients were on stable antipsychotic treatment by the serotonin reuptake inhibitors (SSRI). Spa treatment was not based on drinking mode or on baths but only on physician activities described in detail elsewhere (Bičíková et al. 2018). Medications and their dosing could not be changed during their spa stay (or patient must be excluded from the study group). Before starting the 4 weeks spa treatment they were informed about the possibility to participate in the study, and after checking-in to the spa signed an informed consent form. The study was approved by the Ethics Committee of the Institute of Endocrinology, Prague. From participating patients we chose a sufficient number of women for statistical evaluation $(\mathrm{n}=70)$ with similar ages ranging from 52-61 years and with the same or similar medications.

The self-rating Neuro-N-5 questionnaire from Knobloch and Hausner was used to evaluate the mental condition of each patient (Novotný et al. 2005).

\section{Blood sampling}

On the third day of their stay (after the initial stress of a changed environment and diet), $10 \mathrm{ml}$ of blood was taken in the morning after fasting into an EDTA blood sampling tube, centrifuged within a half hour, and plasma stored in a freezer at $-20{ }^{\circ} \mathrm{C}$ until processing. The second sampling was performed similarly on the next-tolast day of their stay. The patients were instructed not to eat nuts, bananas, or tomatoes, and not drink coffee or black tea for the two days prior to sampling.

\section{Determination of homocysteine and serotonin}

Determination of homocysteine was detected by gas chromatography-mass spectrometry according to Husek (2000).

Serotonin was determined by laboratory in-house method, briefly as follows: Serotonin was purified from sample by two successive SPE extractions. First extraction is based on weakly acidic and second on strongly basic cation exchanger. Sample with borate buffer is applied to first SPE column, washed by water and extracted by diluted ammonia. This extract is applied on second SPE column, washed by water and extracted by citrate buffer. Final extract is injected into HPLC system.

\section{Determination of steroids (steroid metabolome)}

Steroid metabolome (95 steroids and their 
metabolites) was determined using a GCMS-TQ8040 system from Shimadzu (Kyoto, Japan) consisting of a gas chromatograph equipped with an automatic flow control, an AOC-20s autosampler and a triple quadrupole detector with an adjustable electron voltage of 10-195 V. The analysis was conducted in multiple reaction monitoring
(MRM) mode. A capillary column with a medium polarity RESTEK Rtx-50 column (diameter $0.25 \mathrm{~mm}$, length $15 \mathrm{~m}$, film thickness $0.1 \mu \mathrm{m}$ ) was used for analyses. Electron-impact ionization with electron voltage fixed at $60 \mathrm{~V}$ and emission current set to $151 \mu \mathrm{A}$ was used for the measurements (Table 1: GC) (Hill et al. 2018).

Table 1. The effects of spa treatment on the levels of laboratory parameters (median with quartiles) evaluated using the Wilcoxon robust paired test.

\begin{tabular}{|c|c|c|c|c|}
\hline Variable & Unit & $\begin{array}{c}\text { Beginning } \\
\text { of treatment }\end{array}$ & $\begin{array}{c}\text { Change } \\
{[\%]}\end{array}$ & $\begin{array}{c}\text { Significance of } \\
\text { the change } \\
\text { p-value }\end{array}$ \\
\hline Serotonin & $\mathrm{nM}$ & $114(43.5,386)$ & $23.1(-8.27,85.9)$ & 0.001 \\
\hline Homocysteine & $\mu \mathrm{M}$ & $14.8(12.1,16.7)$ & $-17.1(-24.8,0.0276)$ & 0.002 \\
\hline Pregnenolone (LC) & $\mathrm{nM}$ & $1.45(0.618,2.37)$ & $44.5(-9.04,146)$ & 0.000 \\
\hline 17-hydroxy-pregnenolone (LC) & $\mathrm{nM}$ & $1.93(1.16,5.32)$ & $29.6(-19.7,203)$ & 0.001 \\
\hline DHEA (LC) & $\mathrm{nM}$ & $9.73(5.69,14.4)$ & $16.4(-17.7,50.4)$ & 0.007 \\
\hline $7 \alpha$-hydroxy-DHEA (LC) & $\mathrm{nM}$ & $1.28(0.914,2.05)$ & $10.8(-17,54.3)$ & 0.009 \\
\hline Cortisol (RIA) & $\mathrm{nM}$ & $467(383,612)$ & $18.3(-2.9,43.1)$ & 0.000 \\
\hline Pregnenolone sulfate (GC) & $\mathrm{nM}$ & $88.5(58.5,114)$ & $10.9(-7.45,25.3)$ & 0.012 \\
\hline 17-hydroxy-pregnenolone sulfate $(G C)$ & $\mathrm{nM}$ & $3.58(2.24,5.7)$ & $31(-12.1,74.7)$ & 0.001 \\
\hline 16a-hydroxy-pregnenolone $(G C)$ & $\mathrm{nM}$ & $0.337(0.216,0.513)$ & $14.6(-19.2,87.4)$ & 0.014 \\
\hline Androstendiol (GC) & $\mathrm{nM}$ & $1.53(1.09,2.3)$ & $6.16(-12.5,32.9)$ & 0.034 \\
\hline 17-hydroxy-progesterone (GC) & $\mathrm{nM}$ & $0.77(0.502,1.32)$ & $36(-28,99.4)$ & 0.011 \\
\hline 16a-hydroxy-progesterone (GC) & $\mathrm{nM}$ & $0.511(0.287,1.06)$ & $19.2(-33.6,145)$ & 0.008 \\
\hline Androstendion (GC) & $\mathrm{nM}$ & $3.65(2.27,5.08)$ & $9.76(-19.4,49.4)$ & 0.012 \\
\hline Isopregnanolone sulfate (GC) & $\mathrm{nM}$ & $8.16(5.63,11.2)$ & $5.53(-9.32,26.5)$ & 0.046 \\
\hline Conjugated epipregnanolone (GC) & $\mathrm{nM}$ & $2.31(1.14,3.29)$ & $7.36(-13.9,30.6)$ & 0.049 \\
\hline $5 \alpha$-pregnane- $3 \alpha, 20 \alpha$-diol $(G C)$ & $\mathrm{nM}$ & $0.0566(0.0331,0.109)$ & $9.24(-41,87.6)$ & 0.041 \\
\hline Conjugated $5 \alpha$-pregnane-3 $3,20 \alpha$-diol $(G C)$ & $\mathrm{nM}$ & $6.85(4.96,12)$ & $-11(-28.3,9.23)$ & 0.019 \\
\hline Conjugated $5 \alpha$-pregnane- $3 \alpha, 17 \alpha, 20 \alpha$-triol (GC) & $\mathrm{nM}$ & $26.4(14.3,60.9)$ & $185(40,416)$ & 0.000 \\
\hline Epiandrosterone (GC) & $\mathrm{nM}$ & $1.09(0.762,1.58)$ & $14.8(-17.3,40.9)$ & 0.025 \\
\hline Epietiocholanolone sulfate (GC) & $\mathrm{nM}$ & $43(26.9,72.2)$ & $20.4(-1.88,36.4)$ & 0.000 \\
\hline Conjugated $5 \beta$-androstane- $3 \beta, 17 \beta$-diol (GC) & $\mathrm{nM}$ & $0.675(0.373,1.13)$ & $13.7(-13.7,54.7)$ & 0.026 \\
\hline Corticosterone (GC) & $\mathrm{nM}$ & $6.68(3.57,10.5)$ & $21.6(-16.4,122)$ & 0.001 \\
\hline $3 \alpha, 5 \alpha$-tetrahydrocorticosterone & $\mathrm{nM}$ & $0.0704(0.0341,0.212)$ & $40.6(-41.9,137)$ & 0.008 \\
\hline $11 \beta$-hydroxy-androstenedione & $\mathrm{nM}$ & $171(101,275)$ & $13.3(-12.6,53.7)$ & 0.003 \\
\hline
\end{tabular}

The significance of the changes of the individual values before and after treatment (in \% of the shift) were calculated by the Wilcoxon robust paired test.

Selected steroids were detected by the method LC/MS/MS (Table 1: LC). Estrone (E1), estradiol (E2) and estriol (E3) were quantified using previously published LC-MS/MS method. Cortisol, cortisone, dehydroepiandrosterone (DHEA), 7a-hydroxydehydroepiandrosterone (7 $\alpha$-OH-DHEA), 7 $\beta$-hydroxydehydroepiandrosterone (7ß-OH-DHEA), 7-oxo- dehydroepiandrosterone (7-oxo-DHEA), pregnenolone, 17 $\alpha$-hydroxy-pregnenolone (17-OH-pregnenolone), testosterone, androstendione, progesterone, $17-\mathrm{OH}-$ progesterone, corticosterone were determined using another LC-MS/MS validated method (Sosvorova et al. 2015b, Vitku et al. 2015). 


\section{Results}

A summary of results given as basal values and relative differences before and after treatment were evaluated by the Wilcoxon test and is given in the attached Table 1.

We included those results where the differences in the measured parameters between the start and the end of the treatment were found statistically significant. Though the medians of the hormone levels at the beginning of spa stay and at the end of the treatment are not much different, the parameters of the individual patients evaluated by Wilcoxon test show significant differences in 21 steroids from 94 steroids analyzed.

In average, serotonin increased by a relative $23 \%$, while homocysteine decreased by $17.1 \%$. These two values by themselves attest to the positive benefits of spa treatments, and provide evidence for the fact that the patients felt better.

Next group of steroids and their metabolites reflects activation of the adrenal cortex whose seemingly small changes all together can have far-reaching influence in patients under the SSRI medications (Hinkelmann et al. 2012). These results serve as objective parameters for patients well-being.

\section{Discussion}

Our results indicate changes in HPA (hypothalamic-pituitary-adrenal) axis activity. The increased cortisol levels (by $18.3 \%$ ) were within physiological ranges, showing that for these patients being "normal" was evidence of their increased wellbeing. Cortisol plays multifaceted role in major depression disorder. On one side, higher cortisol and disturbed diurnal rhythm lead to higher risk of some subtypes of depression disorder (Herbert 2013). On the other hand, cortisol levels were significantly lower for the whole group of depressive suicide attempters compared to controls (Papadopoulou et al. 2017). In addition, studies have shown that the cortisol levels are blunted in some patients with psychiatric disorders, and thus slight increases in cortisol levels may be interpreted as approaching a normal state (Borges et al. 2013, Papadopoulos and Cleare 2011).

Pregnenolone increased by a relative $44.5 \%$. This steroid stands at the beginning of the production of all steroid hormones (including the neuroactive mentioned above), and is considered by both the scientific and lay communities as a substance increasing mental activity and providing neuro-protection (Bianchi and Baulieu 2012, Marx et al. 2011). There was a similar relative increase of $40.6 \%$ for $3 \alpha, 5 \alpha$-tetrahydrocorticosterone, which is considered an endogenic molecule with strong anti-inflammatory effects.

Pregnenolone contributes to the production of other highly active metabolites. Pregnane metabolites that have a hydroxy group at position $3 \alpha$ - positively modulate the above-mentioned $\mathrm{GABA}_{\mathrm{A}}$ receptors (which increased by $12.5 \%$ on average), leading to reduced stress, relaxation, and a good mood.

A very important finding is that of increased levels of DHEA and pregnenolone sulfate (by $16.4 \%$ and $10.9 \%$, respectively), which positively modulate the above mentioned NMDA receptors, leading to overall organism stimulation, higher attentions, and positive thinking (Vallee et al. 2001).

Another very positive finding is that of the hydroxylated metabolite of DHEA (e.g. $7 \alpha-O H-D H E A)$ increases during the treatment. This steroid is strongly immuno-protective, acting against the autoimmune processes to which neuropsychiatric patients are at risk.

Increased levels of conjugated steroids, both glucuronide and sulfate, are very important, since their effects are long-lasting. It can therefore be concluded that total overall improvements in the psychological status of patients induced by substances supporting immunity and those protecting against autoimmune reactions do not disappear right after spa treatments end and they return to normal life.

Serum serotonin increased by a relative $23 \%$, that naturally reflects increases the serotonin neuromodulator concentration in the synapse, which is the primary purpose of antidepressant therapy (Bigelow and Edgar 2006).

To conclude, the study found changes in steroid hormones that are known to have neuroactive effects. We investigated changes in peripheral blood that reflect changes that affect also the brain activity. This finding within the context of the entire steroid spectrum shows a shift in adrenal activity and gives an idea of how spa treatment affects hormonal parameters. Thus, although the changes of the individual steroids are small, there is a shift and other adjustment of the whole steroid metabolism. To results achieved, it is necessary to approach complexly as a shift and the overall state improvement rather than to analyze individual steroids. Regarding the constant medication before and during the stay in the spa, the observed changes can be attributed to 
the positive effect of spa treatment.

If patients follow the basic principles that they learn during their spa stays, namely activity in fresh air, plenty of sleep, and a diet rich in vitamins, there is hope that the positive changes, especially overall improvement in the mental condition, the increase in immune suppressive substances and anti-autoimmune responses they experience may persist many weeks.

\section{Conflict of Interest}

There is no conflict of interest.

\section{Acknowledgements}

Supported by MH CZ - DRO (Institute of Endocrinology - EÚ, 00023761) and OPPK CZ.2.16/3.1.00/21518

"Equipment for metabolomics research".

\section{References}

BHATIA P, SINGH N: Homocysteine excess: delineating the possible mechanism of neurotoxicity and depression. Fundam Clin Pharmacol 29: 522-528, 2015.

BIANCHI M, BAULIEU EE: 3beta-methoxy-pregnenolone (MAP4343) as an innovative therapeutic approach for depressive disorders. Proc Natl Acad Sci U S A 109: 1713-1718, 2012.

BICIKOVA M, HILL M, RIPOVA D, MOHR P: Altered levels of circulating GABAergic 5alpha/beta-reduced pregnane and androstane steroids in schizophrenic men. Horm Mol Biol Clin Investig 6: 227-230, 2011.

BICIKOVA M, HILL M, RIPOVA D, MOHR P, HAMPL R: Determination of steroid metabolome as a possible tool for laboratory diagnosis of schizophrenia. J Steroid Biochem Mol Biol 133: 77-83, 2013.

BICIKOVA M, DUSKOVA M, VITKU J, KALVACHOVA B, RIPOVA D, MOHR P, STARKA L: Vitamin D in anxiety and affective disorders. Physiol Res 64 (Suppl 2): S101-S103, 2015.

BIČÍKOVÁ M, KOLÁTOROVÁ L, MÁČOVÁ L, BEŠŤÁK J, HILL M, FORMANOVÁ P, JANDOVÁ D, MORÁVEK O, NOVOTNÝ J: Steroidal metabolomic biomarkers as an indicator of the effect of spa therapy and balneotherapy (in Czech). Lék Fyz Reh 25 (3): 2018.

BIGELOW BC, EDGAR KJ: UXL Encyclopedia of Drugs \& Addictive Substances. UXL, Detroit, 2006.

BORGES S, GAYER-ANDERSON C, MONDELLI V: A systematic review of the activity of the hypothalamicpituitary-adrenal axis in first episode psychosis. Psychoneuroendocrinology 38: 603-611, 2013.

COMPAGNONE NA, MELLON SH: Neurosteroids: biosynthesis and function of these novel neuromodulators. Front Neuroendocrinol 21: 1-56, 2000.

DUSKOVA M, HILL M, BICIKOVA M, SRAMKOVA M, RIPOVA D, MOHR P, STARKA L: The steroid metabolome in men with mood and anxiety disorders. Physiol Res 64 (Suppl 2): S275-S282, 2015.

GIBSON EL: Tryptophan supplementation and serotonin function: genetic variations in behavioural effects. Proc Nutr Soc 77: 174-188, 2018.

GUENNOUN R, LABOMBARDA F, GONZALEZ DENISELLE MC, LIERE P, DE NICOLA AF, SCHUMACHER $\mathrm{M}$ : Progesterone and allopregnanolone in the central nervous system: response to injury and implication for neuroprotection. J Steroid Biochem Mol Biol 146: 48-61, 2015.

HAMPL R, BICIKOVA M: Neuroimmunomodulatory steroids in Alzheimer dementia. J Steroid Biochem Mol Biol 119: 97-104, 2010.

HERBERT J: Cortisol and depression: three questions for psychiatry. Psychol Med 43: 449-469, 2013.

HILL M, HÁNA V, VELÍKOVÁ M, KOLÁTOROVÁ L, VÍTKU゚ J, ŠKODOVÁ T, ŠIMKOVÁ M, PAŘÍZEK A, ŠIMJÁK P, KANCHEVA R, KOUCKÝ M, KOKRDOVÁ Z, ADAMCOVÁ K, ČERNÝ A, HÁJEK Z, DUŠKOVÁ M, BULANT J, STÁRKA L: A method for determination of one hundred endogenous steroids in human serum by gas chromatography-tandem mass spectrometry. J Steroid Biochem Mol Biol in press 2018.

HINKELMANN K, MORITZ S, BOTZENHARDT J, MUHTZ C, WIEDEMANN K, KELLNER M, OTTE C: Changes in cortisol secretion during antidepressive treatment and cognitive improvement in patients with major depression: a longitudinal study. Psychoneuroendocrinology 37: 685-692, 2012.

HUSEK P: Determination of homocysteine by gas chromatography-mass spectrometry following treatment with chloroformates: a comment. J Chromatogr B Biomed Sci Appl 740: 289-290, 2000. 
JOLING M, VAN DEN HEUVEL OA, BERENDSE HW, BOOIJ J, VRIEND C: Serotonin transporter binding and anxiety symptoms in Parkinson's disease. J Neurol Neurosurg Psychiatry 89: 89-94, 2018.

MARX CE, BRADFORD DW, HAMER RM, NAYLOR JC, ALLEN TB, LIEBERMAN JA, STRAUSS JL, KILTS JD: Pregnenolone as a novel therapeutic candidate in schizophrenia: emerging preclinical and clinical evidence. Neuroscience 191: 78-90, 2011.

MORETTI R, CARUSO P, DAL BEN M, CONTI C, GAZZIN S, TIRIBELLI C: Vitamin D, homocysteine, and folate in subcortical vascular dementia and Alzheimer dementia. Front Aging Neurosci 9: 169, 2017.

NOVOTNÝ J, JANDOVÁ D, KUBÁNEK J, VAŘEKA J: Possibilities of using the self-judging scale N-5 in diagnostic practice (in Czech). Praktický lékař: časopis pro další vzdělávání lékař̃ 85: 575-577, 2005.

PAPADOPOULOS AS, CLEARE AJ: Hypothalamic-pituitary-adrenal axis dysfunction in chronic fatigue syndrome. Nat Rev Endocrinol 8: 22-32, 2011.

PAPADOPOULOU A, DOUZENIS A, CHRISTODOULOU C, GOURNELLIS R, PAPAGEORGIOU C, MARKIANOS M: Association of plasma cortisol levels with clinical characteristics of suicide attempters. Neuropsychobiology 76: 161-165, 2017.

REDDY DS: Pharmacology of endogenous neuroactive steroids. Crit Rev Neurobiol 15: 197-234, 2003.

ROMER B, LEWICKA S, KOPF D, LEDERBOGEN F, HAMANN B, GILLES M, SCHILLING C, ONKEN V, FRANKHAUSER P, DEUSCHLE M: Cortisol metabolism in depressed patients and healthy controls. Neuroendocrinology 90: 301-306, 2009.

SCHUMACHER M, LIERE P, AKWA Y, RAJKOWSKI K, GRIFFITHS W, BODIN K, SJOVALL J, BAULIEU EE: Pregnenolone sulfate in the brain: a controversial neurosteroid. Neurochem Int 52: 522-540, 2008.

SOSVOROVA L, BESTAK J, BICIKOVA M, MOHAPL M, HILL M, KUBATOVA J, HAMPL R: Determination of homocysteine in cerebrospinal fluid as an indicator for surgery treatment in patients with hydrocefalus. Physiol Res 63: 521-527, 2014.

SOSVOROVA L, MOHAPL M, HILL M, STARKA L, BICIKOVA M, VITKU J, KANCEVA R, BESTAK J, HAMPL R: Steroid hormones and homocysteine in the outcome of patients with normal pressure hydrocephalus. Physiol Res 64 (Suppl 2): S227-S236, 2015 a.

SOSVOROVA L, VITKU J, CHLUPACOVA T, MOHAPL M, HAMPL R: Determination of seven selected neuro- and immunomodulatory steroids in human cerebrospinal fluid and plasma using LC-MS/MS. Steroids 98: 1-8, $2015 b$.

VALLEE M, MAYO W, LE MOAL M: Role of pregnenolone, dehydroepiandrosterone and their sulfate esters on learning and memory in cognitive aging. Brain Res Brain Res Rev 37: 301-312, 2001.

VITKU J, CHLUPACOVA T, SOSVOROVA L, HAMPL R, HILL M, HERACEK J, BICIKOVA M, STARKA L: Development and validation of LC-MS/MS method for quantification of bisphenol A and estrogens in human plasma and seminal fluid. Talanta 140: 62-67, 2015. 